\title{
Airway hyperresponsiveness: relation to asthma and inflammation?
}

Bronchial hyperresponsiveness, or airway hyperresponsiveness to acknowledge incomplete understanding of the precise anatomical site involved, is an exaggerated constrictor response to various stimuli. Airway hyperresponsiveness has been recognised for over 50 years and, although associated with a number of bronchial diseases, is considered a key feature of asthma which correlates with severity of disease, frequency of symptoms, and need for treatment. ${ }^{1}$ Asthma is characterised by spontaneous changes in airway calibre which can be documented by serial peak flow measurements. Wide variation in airflow limitation is an index of asthma severity and patients with considerable diurnal variation in peak flow are susceptible to acute bronchoconstriction to environmental stimuli. The extent of susceptibility can be assessed in the laboratory by bronchoconstrictor challenge tests which measure the responsiveness of the airways. Inhalation of histamine or methacholine is a commonly used challenge with the concentration of spasmogen provoking a $20 \%$ fall in forced expiratory volume in one second $\left(\mathrm{PC}_{20} \mathrm{FEV}_{1}\right)$ used as an index of airway responsiveness.

The pathogenesis of airway hyperresponsiveness is unclear, although in asthma it is linked with inflammation. ${ }^{23}$ Airway responsiveness in stable asthmatic patients is related to numbers of eosinophils and mast cells in bronchoalveolar lavage fluid, ${ }^{4}$ extent of mucosal inflammation, ${ }^{5}$ and peripheral blood eosinophilia. ${ }^{6}$ Airway hyperresponsiveness to histamine or methacholine is not unique to asthma and is demonstrable in patients with other lung disorders involving airway inflammation including chronic obstructive pulmonary disease (COPD), ${ }^{7}$ sarcoidosis, ${ }^{8}$ bronchiectasis, ${ }^{9}$ and in patients after heart-lung transplantation. ${ }^{10}$

Although many studies have found evidence of inflammation in the airways of asthmatic patients, a recent survey ${ }^{11}$ has indicated a number of studies which failed to find significant inflammatory changes. In addition, a number of bronchial diseases in which airway hyperresponsiveness is not a key feature exhibit considerable airway inflammation including interstitial lung disease, AIDS associated pneumonia, and eosinophilic pneumonia. ${ }^{12}$ Conversely, a proportion of people without clinical lung disease exhibit airway hyperresponsiveness. ${ }^{13}$ In this issue of Thorax (pp 1125-1129), Power and colleagues make the observation that airway hyperresponsiveness and inflammatory cell infiltration are not necessarily linked. ${ }^{14}$ These authors found that a third of their 27 clinically normal subjects exhibited airway hyperresponsiveness, defined by a $\mathrm{PC}_{20} \mathrm{FEV}_{1}$ to histamine of $\leqslant 8 \mathrm{mg} / \mathrm{ml}$, in the absence of any inflammatory cell infiltration: $T$ lymphocytes, eosinophils, mast cells, or antigen presenting cells. The extent of activation of the inflammatory cells was not determined. The authors conclude that airway hyperresponsiveness as currently defined is independent of immunopathological changes in the bronchial wall, nor does bronchial hyperresponsiveness necessarily reflect subclinical inflammation.

Several recent studies develop the concept of normal airway responsiveness. Airway responsiveness to histamine is distributed continuously in human subjects in a log-normal manner with no clear cutoff between normal and increased airway responsiveness despite an arbitrary definition of hyperresponsiveness of a $\mathrm{PC}_{20} \mathrm{FEV}_{1}$ to histamine of $<8 \mathrm{mg} / \mathrm{ml} .{ }^{15} \mathrm{Up}$ to $50 \%$ of subjects with no evidence of asthma or other respiratory disease can be categorised as having mild airway hyperresponsiveness $\left(\mathrm{PC}_{20}\right.$ to histamine of $\left.2-8 \mathrm{mg} / \mathrm{ml}\right) .{ }^{1516}$ Thus, airway hyperresponsivness is not diagnostic of asthma; rather it is a functional disorder reflecting a tendency to airflow obstruction. In epidemiological surveys of asthma, diagnosis is based on airway hyperresponsiveness in combination with a history of wheeze in the previous year. ${ }^{17}$ In clinical practice, inhalation challenges with histamine or methacholine are useful to exclude asthma because of their high sensitivity and high negative predictive value. ${ }^{18}$ However, these challenges are not suitable for confirming a diagnosis of asthma because of their low specificity and low positive predictive value. The sensitivity and specificity of histamine or methacholine challenges are partly dependent on the cutoff values distinguishing hyperresponsiveness from normal responsiveness. The histamine cutoff of $8 \mathrm{mg} / \mathrm{ml}$ has recently been questioned as being too high, ${ }^{19}$ a suggestion borne out by Power et al. ${ }^{14}$ A $\mathrm{PC}_{20} \mathrm{FEV}_{1}$ for histamine of $<2 \mathrm{mg} / \mathrm{ml}$ might be a useful diagnostic cutoff in patients with symptoms of asthma in the absence of documented variable airflow limitation. This still will not exclude COPD or other respiratory disorders where responses to histamine are often indistinguishable between patients with asthma or COPD. In the diagnosis and management of asthma, measurement of airway hyperresponsiveness is no substitute for monitoring clinical parameters: symptoms, spirometric measurements, serial peak flow readings, and rate of consumption of inhaled $\beta$ agonists.

The relatively poor specificity for asthma of histamine or methacholine challenge indicates that more appropriate laboratory tests of airway responsiveness need to be established. Physical stimuli including cold air, fog, or exercise have the advantage of mimicking naturally encountered bronchoconstrictor stimuli and may be a truer reflection of clinical asthma. ${ }^{20}$ The underlying mechanisms are indirect, involving cellular and neural pathways which may be abnormal in asthma. ${ }^{23}$ In contrast, histamine and methacholine act directly on appropriate receptors on the airway smooth muscle which have not been shown to be abnormal in asthma. ${ }^{212} \mathrm{~A}$ positive bronchoconstrictor response to exercise or cold air is consistent with a diagnosis of asthma, although a negative response does not exclude asthma. Physical stimuli have a number of disadvantages: they involve dedicated and expensive laboratory equipment, cannot be administered in graded dose increments, have not been fully standardised, and are potentially more hazardous to the patient than pharmacological challenge. Assessment of airway hyperresponsiveness with indirect bronchoconstrictor stimuli, however, may provide information about pathophysiological mechanisms in asthma. For example, adenosine 5'-monophosphate (a putative mast cell stimulus) and the neural stimulants bradykinin and sodium metabisulphite overcome problems of physical challenges as they are administered in a similar manner to histamine. ${ }^{18}$

The relation between airway inflammation and airway hyperresponsiveness in asthma remains unclear. Inhaled corticosteroids abolish the symptoms of asthma and 
suppress airway inflammation. ${ }^{232324}$ However, airway hyperresponsiveness, although reduced, persists despite treatment with corticosteroids. ${ }^{24}{ }^{25}$ Genetic and environmental factors contribute to "baseline" airway hyperresponsiveness which appears to be an endogenous defect in asthma. ${ }^{26}$ Transient increases in hyperresponsiveness relate to exposure to allergen and occupational sensitisers. ${ }^{18}$ These "inciters" stimulate influx of inflammatory cells into the airways and provoke asthma attacks. Exacerbations of asthma are therefore associated with increased airway inflammation which results in transient increases in hyperresponsiveness and need for treatment. ${ }^{19}$ Revision of the definitions of bronchial hyperresponsiveness and of the assessment of inflammation are required, not only to understand asthma more completely, but also to rationalise what is good treatment in asthma.

\section{DUNCAN F ROGERS BRIAN J O'CONNOR Department of Thoracic Medicine, National Heart and Lung Institute,}

Reprint requests to: Dr D F Rogers

1 Hargreave FE, Ryan G, Thomson NC, et al. Bronchial responsiveness to histamine or methacholine in asthma: measurement and clinical significance. 7 Allergy Clin Immunol 1981;68:347-55.

2 Barnes PJ. New concepts in the pathogenesis of bronchial hyperresponsiveness and asthma. $\mathcal{f}$ Allergy Clin Immunol 1989;83:1013-26.

3 Chung KF. Role played by inflammation in the hyperreactivity of the airways in asthma. Thorax 1986;41:657-62.

4 Wardlaw AJ, Dannette S, Gleich GJ, Collins JV, Kay AB. Eosinophils and mast cells in bronchoalveolar lavage in subjects with mild asthma: relationship to bronchial hyperreactivity. Am Rev Respir Dis 1988;137:62-9.

5 Djukanovic R, Roche WR, Wilson JW, Beasley CRW, Twentyman OP, Howarth PH, et al. Mucosal inflammation in asthma. Am Rev Respir Dis 1990;142:434-7.

6 Taylor KJ, Luksza AR. Peripheral blood eosinophilia and bronchial responsiveness. Thorax 1987;42:452-6.

$7 \mathrm{Du}$ Toit J, Woolcock AJ, Salome CM, Sundrum R, Black JL. Characteristics of bronchial hyperresponsiveness in smokers with chronic airflow limitation. Am Rev Respir Dis 1986;134:498-501.

8 Manresa Presas F, Romero Colomer P, Rodriguez Sanchon B. Bronchial hyperreactivity in fresh stage I sarcoidosis. Ann NY Acad Sci 1986;465 523-9.

9 Pang J, Chan, HS, Sung JY. Prevalence of asthma, atopy, and bronchial hyperreactivity in bronchiectasis: a controlled study. Thorax 1989;44: 948-51.

10 Banner NR, Heaton R, Hollingshead L, Guz A, Yacoub MH. Bronchial reactivity after combined heart-lung transplantation. Thorax 1988;48: 955-9.

11 Smith $\mathrm{H}$. Asthma, inflammation, eosinophils and bronchial hyperresponsiveness. Clin Exp Allergy 1992;22:187-97.

12 Allen JN, Davis WB, Pacht ER. Diagnostic significance of increased bronchoalveolar lavage fluid eosinophils. Am Rev Respir Dis 1990;140: 642-7.

13 Weiss ST, Sparrow D. Airway responsiveness and atopy in the development of chronic lung disease. New York: Raven Press, 1989: 3.

14 Power C, Sreenan S, Hurson B, Burke C, Poulter LW. Distribution of immunocompetent cells in the bronchial wall of clinically healthy subjects showing bronchial hyperresponsiveness. Thorax 1993;48: 1125-9.

15 Cockroft DW, Berscheid BA, Murdock KY. Unimodal distribution of bronchial responsiveness to inhaled histamine in a random population. Chest 1983;83:751-4.

16 Yan K, Salmone C, Woolcock AJ. Rapid method for measurement of bronchial responsiveness. Thorax 1983;38:760-5.

17 Toelle BG, Peat JK, Salome CM, Mellis CM, Woolcock AJ. Toward a definition of asthma for epidemiology. Am Rev Respir Dis 1992;146: 633-7.

18 Sterk PJ, Fabbri LM, Quanjer PH, Cockcroft DW, O'Byrne PM, Anderson SD, et al. Airway responsiveness. Standardised challenge testing with pharmacological, physical and sensitising stimuli in adults. Eur Respir f 1993;6(Suppl 16):53-83.

19 Cockcroft DW. Bronchial hyperresponsiveness. In: Mygind N, Pipkorn U, Dahl R, eds. Rhinitis and asthma. Copenhagen: Munkgaard, 1990: 172-87.

20 Pauwels R, Joos G, van der Straeten M. Bronchial hyperresponsiveness is not bronchial hyperresponsiveness is not bronchial asthma. Clin Allergy 1988;18:317-21.

21 Goldie RG, Spina D, Henry PJ, Lulich KM, Paterson JW. In vitro responsiveness of human asthmatic bronchus to carbachol, histamine, $\beta$-adrenoceptor agonists and theophylline. Br f Clin Pharmacol 1986; 22:669-76.

22 Whicker SD, Armour CL, Black JL. Responsiveness of bronchial smooth muscle from asthmatic patients to relaxant and contractile agonists. Pulmon Pharmacol 1988;1:25-31.

23 Jeffery PK, Godfrey RW, Adelroth E, Nelson F, Rogers A, Johansson SA. Effects of treatment on airway inflammation and thickening of basement membrane reticular collagen in asthma. Am Rev Respir Dis 1992; 145:890-9.

24 Lungren R, Soderberg M, Horstedt P, Sterling R. Morphological studies of bronchial mucosal biopsies from asthmatics before and after ten years of treatment with inhaled steroids. Eur Respir f 1988;1:883-9.

25 O'Connor BJ, Ridge SM, Barnes PJ, Fuller RW. Greater effect of inhaled budesonide on adenosine 5'-monophosphate-induced than on sodium metabisulfite-induced bronchoconstriction in asthma. Am Rev Respir Dis 1992;146:560-4.

26 Paoletti P, Viegi G, Carrozi L. Bronchial hyperresponsiveness, genetic predisposition and environmental factors: importance of epidemiological research. Eur Respir f 1989;5:910-2. 